\title{
WSTĘPNA MIĘDZYNARODOWA WALIDACJA TESTU KOMPETENCJI MORALNO-ETYCZNEJ PIĘTNASTOLATKÓW ${ }^{1}$
}

\begin{abstract}
Streszczenie: Głównym narzędziem stosowanym w międzynarodowym badaniu ETiKInternational jest Test Kompetencji Moralno-Etycznej Piętnastolatków (TKM-EP), opracowany w trakcie realizacji berlińskiego projektu ETiK. W tym artykule podjęto próbę porównania danych zgromadzonych w ramach projektu ETiK i w badaniach ETiKInternational $\mathrm{w}$ Warszawie i Wiedniu. W wyniku walidacji okazało się, że narzędzie to z powodzeniem może służyć nie tylko do określenia kompetencji moralno-etycznej uczniów, lecz również efektywności nauczania szkolnego.
\end{abstract}

Słowa kluczowe: ETiK, kompetencja moralno-etyczna, empiryczne badanie pedagogiczne.

W przedstawionych powyżej raportach z przeprowadzonych już lub będących jeszcze w fazie planowania badań ETiK-International odwoływano się do Testu Kompetencji Moralno-Etycznej Piętnastolatków (TKM-EP), który został opracowany w trakcie realizacji berlińskiego projektu ETiK. Proces konstruowania, empirycznego weryfikowania i socjometrycznej walidacji tego narzędzia został omówiony szczegółowo w pracy zbiorowej pod redakcją obu kierowników projektu - Dietricha Bennera i Roumiany Nikolovej (2016, s. 13-197). Do oceny trafności i rzetelności TKM-EP wykorzystano obszerny zestaw danych uzyskanych $\mathrm{w}$ trakcie wieloletniej pracy nad projektem ETiK. Dane te pochodzą m.in. z Berlina, Hamburga i Brandenburgii. Edukację etyczno-moralną prowadzi się tam w ramach zajęć szkolnych z tak czy inaczej zdefiniowanego przedmiotu lekcyjnego.

Badania przeprowadzone wiosną 2014 roku w Warszawie i Wiedniu były pierwszą próbą wykorzystania TKM-EP poza terytorium Niemiec. W ten sposób otwarta została droga do jego międzynarodowej walidacji. W niniejszym artykule przedstawiono analizę porównawczą danych uzyskanych w projekcie ETiK i w obu

${ }^{1}$ [Tekst został opublikowany w języku niemieckim pt. Ansätze zur Internationalen Validierung des ETiK-Instruments w Benner, Nikolova 2016, s. 273-277 - dop. D.S]. 
pionierskich badaniach ETiK-International oraz próbę określenia na tej podstawie wartości psychometrycznej TKM-EP w perspektywie międzynarodowej.

\section{Płaszczyzna porównania}

Do przeprowadzenia niniejszego porównania z 6084 uczniów i uczennic, których odpowiedzi wykorzystano przy walidacji TKM-EP, wyselekcjonowano 2573 osoby. Pochodziły one z wymienionych powyżej miejsc realizacji projektu ETiK, a mianowicie z: Berlina - 1657 osób, Hamburga - 700 osób i Brandenburgii - 216 osób. Wszystkie one brały udział w zajęciach z etyki lub z ekwiwalentnego przedmiotu.

W badaniu ETiK-International w Warszawie i Wiedniu z powodów, które kierownicy zespołów - Dariusz Stępkowski i Georg Ritzer - wyjaśnili w artykułach przedstawionych powyżej, przeważająca większość uczestników nie uczęszczała na lekcje etyki ani na żaden inny przedmiot szkolny zawierający podobne treści kształcenia. Ta niezaplanowana w gruncie rzeczy przeszkoda przyniosła jednak korzyść polegającą na tym, że przy okazji międzynarodowej walidacji TKM-EP sprawdzono jego przydatność do mierzenia efektywności wykorzystania czasu spędzanego przez uczniów w szkole. Zgodnie ze znaną teorią time-on-task (Walberg 1988), którą rozwija się współcześnie w badaniach nad efektywnością szkolną, należało oczekiwać, że uczniowie i uczennice, którzy uczęszczają na lekcje etyki, w badaniu za pomocą parametrycznego TKM-EP osiągną wyższe wyniki (tj. wartości punktowe) niż ich koledzy i koleżanki nieuczęszczający na zajęcia z tego przedmiotu. W tym kontekście rodzi się pytanie: Czy TKM-EP umożliwia dokonywanie rozróżnienia między obydwiema grupami uczniów? Ta kwestia zostanie rozważona poniżej wraz pytaniem o „kształt” kompetencji moralno-etycznej badanych.

\section{Charakterystyka porównywanej populacji}

Aby w tracie porównywania danych uzyskanych w Warszawie i Wiedniu uniknąć zniekształceń, sprawdzono najpierw, czy wspomniane powyżej dwie grupy uczniów - uczęszczający na zajęcia z etyki i nieuczęszczający na nie - wykazują podobieństwo pod względem zmiennych niezależnych. W badaniu ETiK przyjęto następujące parametry opisujące badaną populację: poziom zdolności kognitywnych, mierzony za pomocą niewerbalnego Kognitives Fähigkeitstest (KFT; Heller, Perleth 2000), deklarowaną liczbę książek znajdujących się w biblioteczce domowej i język najczęściej używany w komunikacji rodzinnej. Jak pokazano na wykresie 1, poziom zdolności kognitywnych uczestników badania niebiorących udziału w lekcjach etyki był nieco wyższy niż tych, którzy na uczęszczali na te zajęcia. Co prawda, siła efektu wyrażona wartością $d$-Cohena $=0,12$ sygnalizuje małą siłę związku między uczęszczaniem i nieuczęszczaniem na lekcje etyki, jednak po sprawdzeniu tej wartości za pomocą statystyki t (t-Studenta) okazało się, że poziom ufności sięga aż 95 proc., co przekonuje o zajściu istotnej statystycznie zależności. 
Wykres 1. Zdolności kognitywne uczniów uczestniczących i nieuczestniczących w lekcjach etyki na podstawie średniej punktów KFT

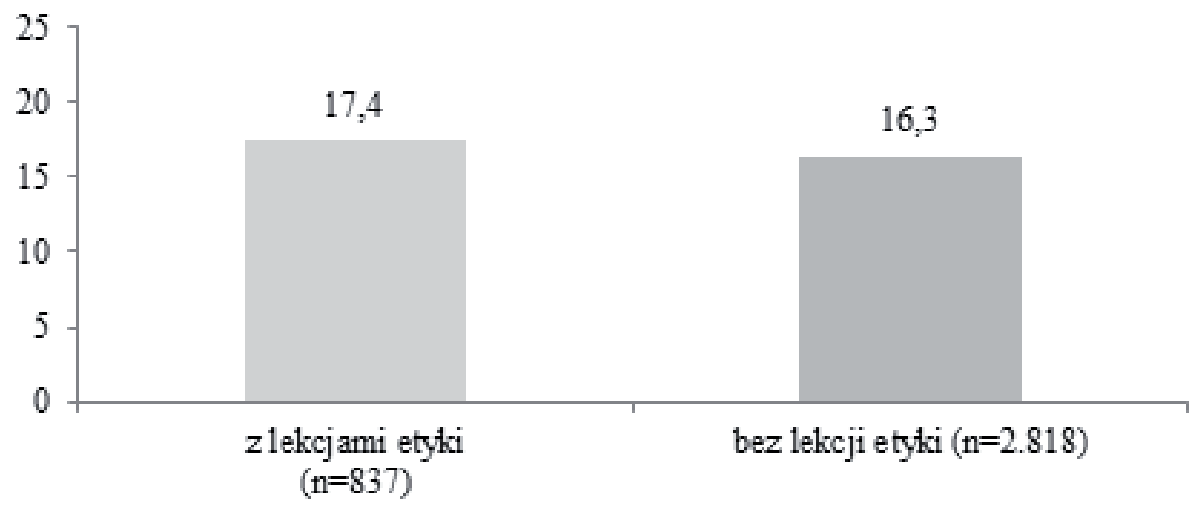

Źródło: opracowanie własne.

Badając kontekst społeczno-kulturowy, poddano analizie dane dotyczące książek znajdujących się w gospodarstwie domowym. Również w tym przypadku okazało się, że uczniowie nieuczęszczający na etykę w szkole znajdują się w lepszej sytuacji. Jak widać na poniższym wykresie, w grupie tej odsetek młodych ludzi pochodzących z rodzin „ubogich” pod względem zasobów książkowych (<10o książek) wynosi 34 proc. i jest o pięć punktów procentowych mniejszy niż w grupie uczniów uczęszczających na zajęcia z etyki.

Wykres 2. Książki posiadane w biblioteczce domowej uczniów uczestniczących i nieuczestniczących w lekcjach etyki

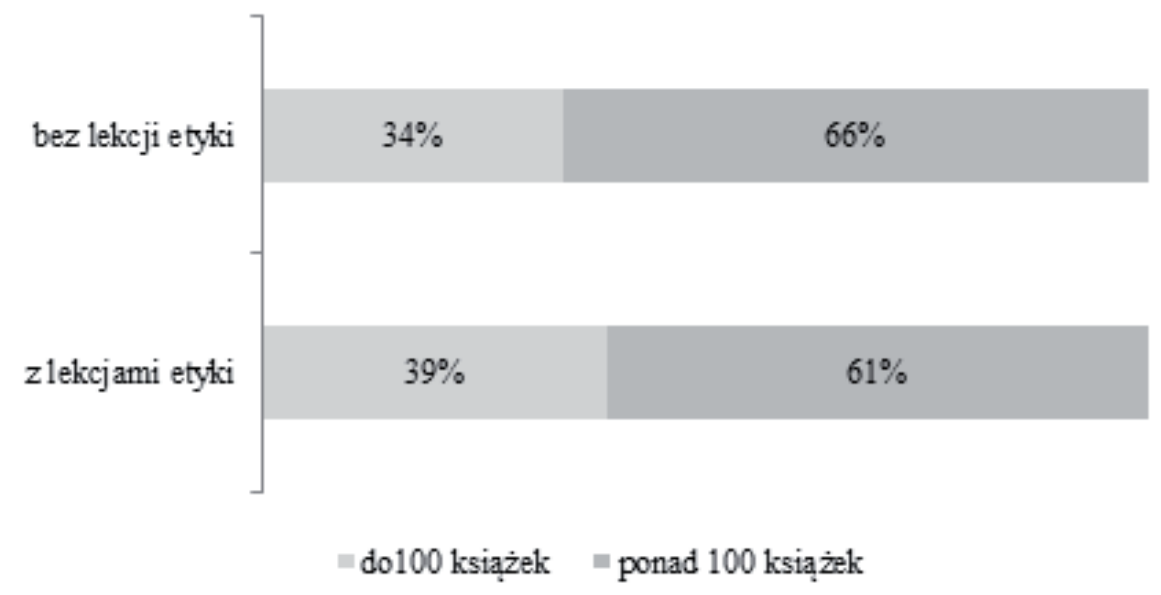

Źródło: opracowanie własne.

Kolejna dysproporcja, jaką ujawniła analiza zgromadzonego materiału empirycznego, dotyczyła struktury populacji pod względem płci. W grupie respondentów 
nieuczestniczących w lekcjach etyki dominującą część stanowiły dziewczęta - 59 proc., natomiast w grupie porównaczej ich udział wynosił zaledwie 45 proc. Całość anlizy obrazuje kolejny wykres.

Wykres 3. Płeć uczniów uczestniczących i nieuczestniczących w lekcjach etyki (w proc.)

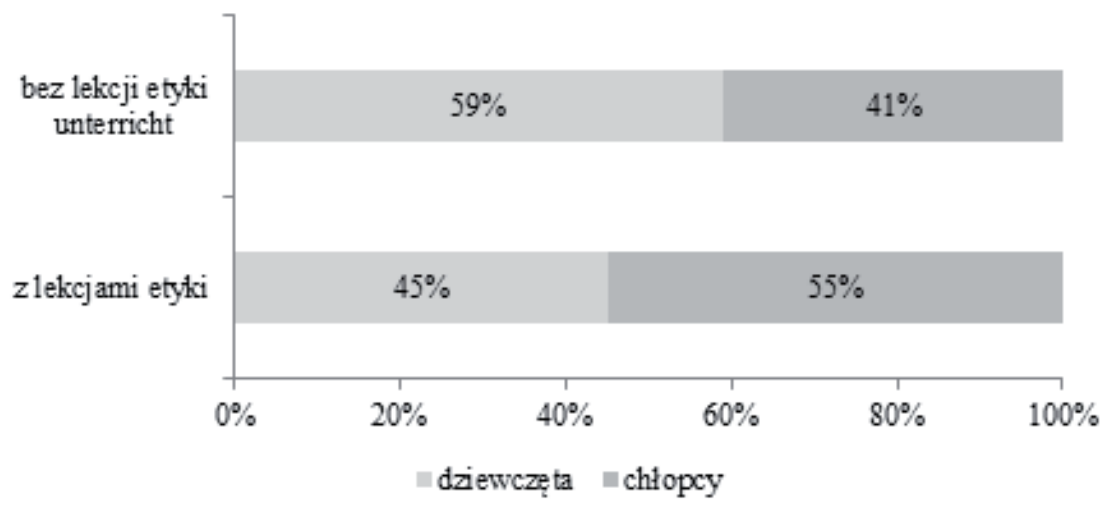

Źródło: opracowanie własne.

Jeżeli chodzi o język dominujący w komunikacji rodzinnej, między obydwiema grupami nie zauważono znaczącej różnicy. Proporcja między uczniami posługującymi się w domu częściej językiem innymi niż w szkole i tymi, którzy mówią tym samym językiem co w szkole, wynosiła w każdej z dwóch grup jak jeden do trzech (wykres 4).

Wykres 4. Język dominujący w komunikacji domowej u uczniów uczestniczących i nieuczestniczących w lekcjach etyki (w proc.)

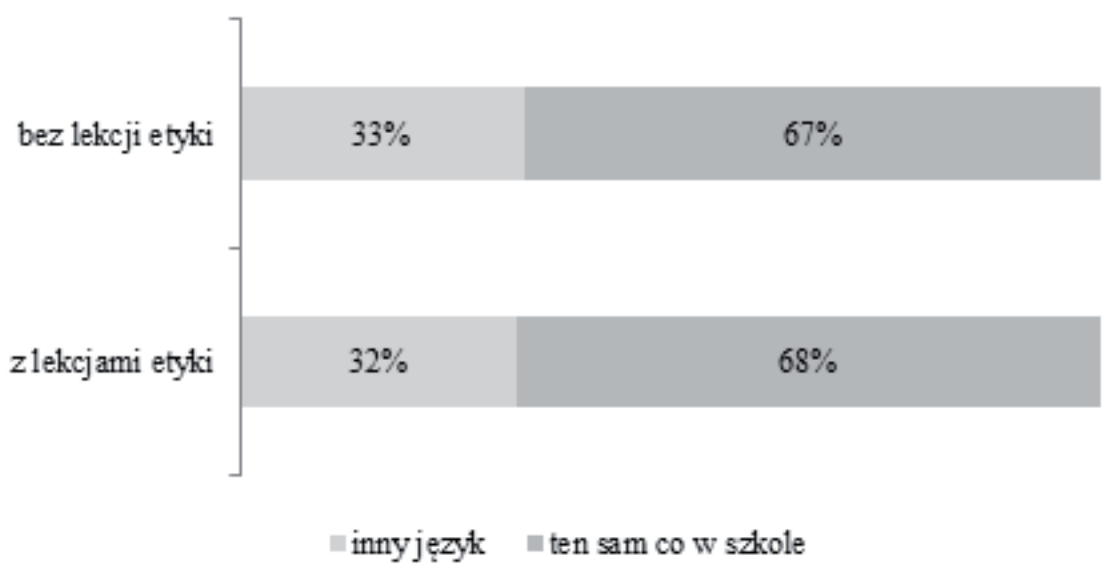

Źródło: opracowanie własne. 
Powyższe wyniki przekonują, że w badaniach wzięła udział populacja uczniów, którą ze względów statystycznych można uznać za homogeniczną.

\section{Kompetencja moralno-etyczna}

Przechodząc do problemu walidacji narzędzia opracowanego w projekcie ETiK i zastosowanego następnie w badaniu ETiK-International w Warszawie i Wiedniu, porównano dane uzyskane $\mathrm{w}$ odniesieniu do trzech skal kompetencji moralno-etycznej, a mianowicie: podstawowej wiedzy moralno-etycznej (PWM-E), kompetencji sądzenia moralno-etycznego (KSM-E) i kompetencji projektowania działania moralno-etycznego (KPDM-E). Analiza wyników przekonuje o tym, że uczniowie uczęszczający na lekcje etyki, mimo że znajdują się w nieco mniej korzystych warunkach, jeżeli chodzi o zdolności kognitywne i kontekst społeczno-kulturowy, uzyskali lepsze wyniki we wszystkich trzech skalach od swoich koleżanek i kolegów nieuczęszczających w zajęciach z tego przedmiotu (wykres 5). Wszystkie różnice wartości średnich arytmetycznych potwierdza 95-proc. poziom ufności.

Wykres 5. Średnia arytmetyczna punktów uzyskanych przez uczniów uczęszczających i nieuczęszczających na lekcje etyki w odniesieniu do podstawowej wiedzy moralno-etycznej (PWM-E), kompetencji sądzenia moralno-etycznego (KSM-E) i kompetencji projektowania działania moralno-etycznego (KPDM-E)

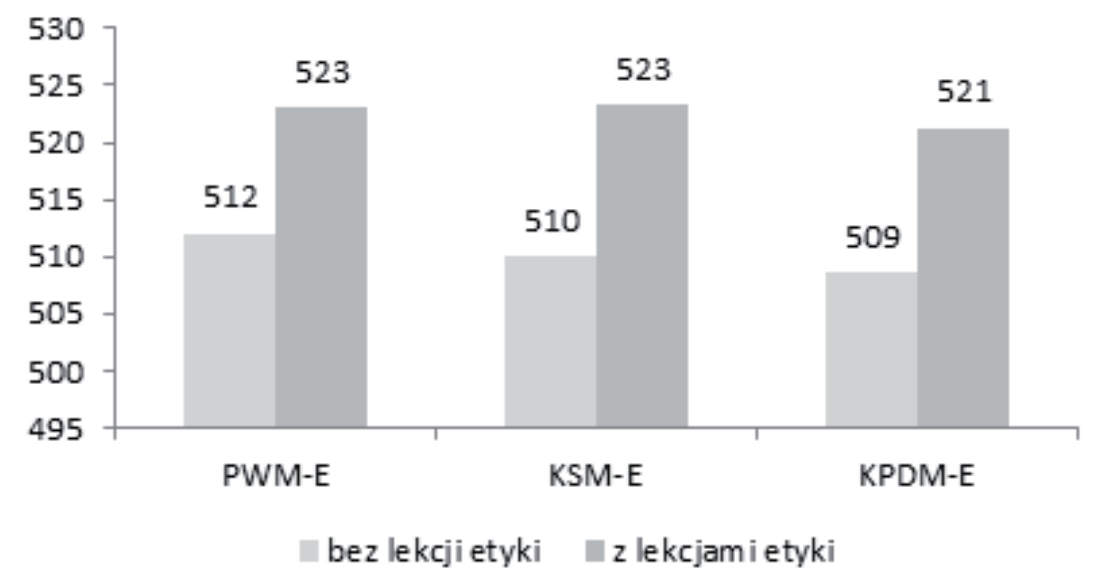

Źródło: opracowanie własne.

Jeszcze wyraźniej widać przewagę osiągniętą przez piętnastolatków biorących udział w lekcjach etyki, gdy skontroluje się z pomocą analizy regresji strukturę tej grupy i weźmie się pod uwagę tylko tych uczniów i te uczennice, którzy wykazują podobieństwa pod względem kontekstu społeczno-kulturowego (wykres 6). 
Wykres 6. Średnia arytmetyczna punktów uzyskanych przez uczniów uczęszczających i nieuczęszczających na lekcje etyki w odniesieniu do podstawowej wiedzy moralno-etycznej (PWM-E), kompetencji sądzenia moralno-etycznego (KSM-E) i kompetencji projektowania działania moralno-etycznego (KPDM-E) po uwzględnieniu kontekstu społeczno-kulturowego

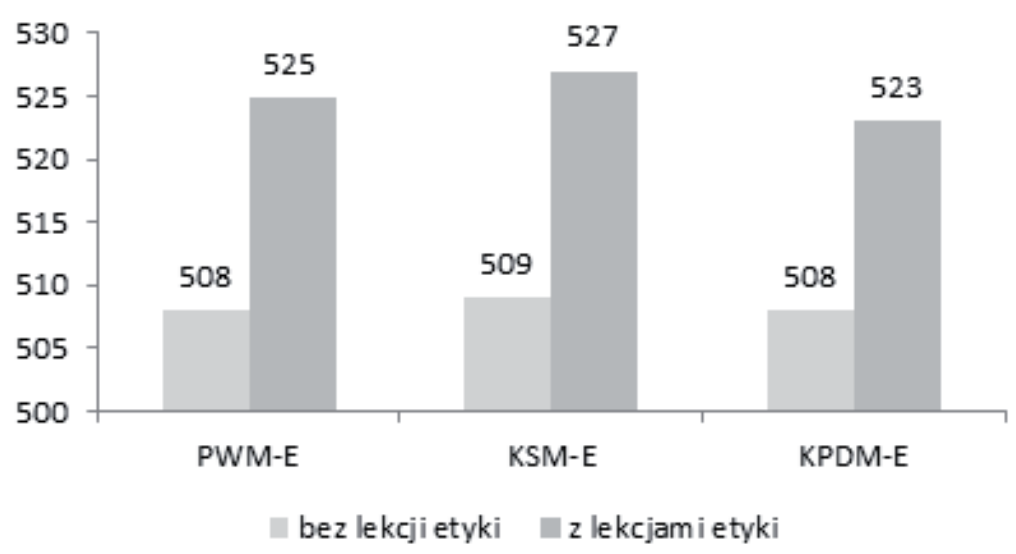

Źródło: opracowanie własne.

W poniższej tabeli zademonstrowano wyniki trzech analiz regresji. Dzięki obliczeniu współczynnika standaryzowanego ß w odniesieniu do trzech wymienionych powyżej skal kompetencyjnych uznano zdolności kognitywne za główny czynnik wpływający na wyniki testu. Czynnikami, które niejako wtórnie oddziałują na wyniki, są natomiast: liczba książek w biblioteczce domowej, płeć i język dominujący w komunikacji rodzinnej. Z kolei cechy związane z przynależnością do odpowiedniej grupy, tzn. uczęszczanie respective nieuczęszczanie na lekcje etyki zakwalifikowano do predyktorów (zmienne niezależne) wyników testu (zmienna zależna). W przeprowadzonych analizach parametry: „liczba książek większa od 100”, „kobieta”, ,język inny niż w szkole”, „piętnastolatek nieuczęszczający na lekcje etyki” pełniły funkcje wielkości referencyjnych i zostały zakodowanie jako „””. W związku z tym dodatnia wartość wskaźnika ß dla predyktora opisującego badaną populację „piętnastolatek nieuczęszczający na lekcje etyki” respective „piętnastolatek uczęszczający na lekcje etyki” wskazuje na przewagę pod względem osiągnięć uczniów i uczennic biorących udział w lekcjach etyki. Natomiast ujemna wartość tych predyktorów jest dowodem przewagi uczniów i uczennic niebiorących udziału w lekcjach etyki. Na podstawie wyników przedstawionych w poniższej tabeli można stwierdzić, że główny predykator użyty do opisu badanej populacji („piętnastolatek nieuczęszczający na lekcje etyki” respective "piętnastolatek uczęszczający na lekcje etyki”) we wszystkich trzech skalach osiąga wartość dodatnią i również współczynnik standaryzowany $ß$ jest na znaczącym poziomie. Ten wynik ponownie potwierdza przewagę osiągnięć uzyskaną przez uczniów uczęszczających na lekcje 
etyki i jednocześnie usuwa zniekształcenia spowodowane różnicami zachodzącymi między obydwiema grupami w odniesieniu do czterech pozostałych predyktorów.

Tabela 1. Zestawienie predyktorów warunkujących wyniki testu w zakresie podstawowej wiedzy moralno-etycznej (PWM-E), kompetencji sądzenia moralno-etycznego (KSM-E) i kompetencji projektowania działania moralno-etycznego (KPDM-E) (współczynnik standaryzowany $ß)$

\begin{tabular}{|c|c|c|c|c|c|}
\hline & KFT & $\begin{array}{c}\text { Grupa } \\
\text { bez lekcji etyki }=\mathbf{0}\end{array}$ & $\begin{array}{c}\text { Płeć } \\
\mathbf{k}=\mathbf{0}\end{array}$ & $\begin{array}{c}\text { Język w rodzinie } \\
\text { inny }=\mathbf{0}\end{array}$ & $\begin{array}{c}\text { Liczba książek } \\
\leq 100=\mathbf{0}\end{array}$ \\
\hline PWM-E & $\mathbf{0 , 1 6 ^ { * * }}$ & $\mathbf{0 , 0 9 ^ { * * }}$ & $\mathbf{0 , 0 6 ^ { * * }}$ & $\mathbf{0 , 1 3 ^ { * * }}$ & $\mathbf{0 , 1 4 ^ { * * }}$ \\
\hline KSM-E & $\mathbf{0 , 1 6 ^ { * * }}$ & $\mathbf{0 , 0 8 ^ { * * }}$ & $\mathbf{0 , 0 4 ^ { * }}$ & $\mathbf{0 , 0 9 ^ { * * }}$ & $\mathbf{0 , 1 4 ^ { * * }}$ \\
\hline KPDM-E & $\mathbf{0 , 1 4 ^ { * * }}$ & $\mathbf{0 , 0 5 ^ { * }}$ & $\mathbf{0 , 0 7 ^ { * * }}$ & $\mathbf{0 , 0 8 ^ { * * }}$ & $\mathbf{0 , 1 0 ^ { * }}$ \\
\hline
\end{tabular}

${ }^{\star} \mathrm{p} \leq 0,05 ;{ }^{* *} \mathrm{p} \leq \mathrm{0}, 01$;

$\mathrm{R}^{2}: \mathrm{PWM}-\mathrm{E}=29,1 ; \mathrm{R}^{2}: \mathrm{KSM}-\mathrm{E}=\mathbf{2 5 , 9}, \mathrm{R}^{2}: \mathrm{KPDM}-\mathrm{E}=\mathbf{2 2 , 9}$

Źródło: opracowanie własne.

Z powyższej tabeli można wyczytać, że zdolności kognitywne uczniów, zgodnie z oczekiwaniami, wnoszą największy wkład w wyniki osiągnięte przez uczniów zobrazowane na wszystkich trzech skalach kompetencji moralno-etycznej. Jednak także uwarunkowania społeczno-kulturowe i etniczne w znaczącym stopniu korelują $\mathrm{z}$ wynikami badania przeprowadzonego za pomocą TKM-EP. Dysproporcje co do osiągnięć wypadają na korzyść uczniów i uczennic, którzy nie wzrastają w środowiskach migracyjnych i pochodzą raczej z rodzin zbliżonych do edukacji. Po uwzględnieniu pozostałych predyktorów okazuje się ponadto, że również płeć ma własną moc wyjaśniania, gdyż w analizowanych trzech skalach kompetencji moralno-etycznej chłopcom przysługuje nad dziewczętami co prawda niewielka, ale jednak pewna przewaga.

Jeżeli spojrzeć na przewagę osiągnieć, jaką uzyskali uczniowie uczęszczający na lekcje etyki, z uwzględnieniem kraju, z którego pochodzą, widać wyraźnie, że dane uzyskane w Warszawie z powodu niewielkiej liczby uczestników biorących udział w zajęciach z etyki i wynikającej stąd dużej dysproporcji między obydwiema grupami, trzeba uznać za zniekształcone. Oprócz skali PWM-E w Warszawie i skali KPDM-E w Wiedniu młodzi ludzie uczęszczający na etykę osiągnęli w obu krajach wyższe wyniki testu niż ich koledzy nieuczęszczający na te zajęcia, przy czym różnica ta w Wiedniu okazuje się nieco wyższa niż w Warszawie. W perspektywie walidacji programowej TKM-EP interesująca i warta zaznaczenie jest obserwacja, że wyniki uzyskane w Wiedniu przez uczniów uczęszczających na etykę na skali PWM-E i KSM-E pokrywają się z wynikami ich kolegów i koleżanek z Berlina, Hamburga i Brandenburgii. Wyjaśnienia tego stanu rzeczy dostarcza wysoka 
zgodność między programami nauczania w obu krajach, na którą w swoim referacie zwrócił uwagę G. Ritzer.

Wykres 7. Średnie wartości punktów uzyskanych przez uczniów uczęszczających i nieuczęszczających na lekcje etyki zobrazowane na skalach: podstawowa wiedza moralno-etyczna (PWM-E), kompetencja sądzenia moralno-etycznego (KSM-E) i kompetencja projektowania działania moralno-etycznego (KPDM-E) w odniesieniu do grup badanych

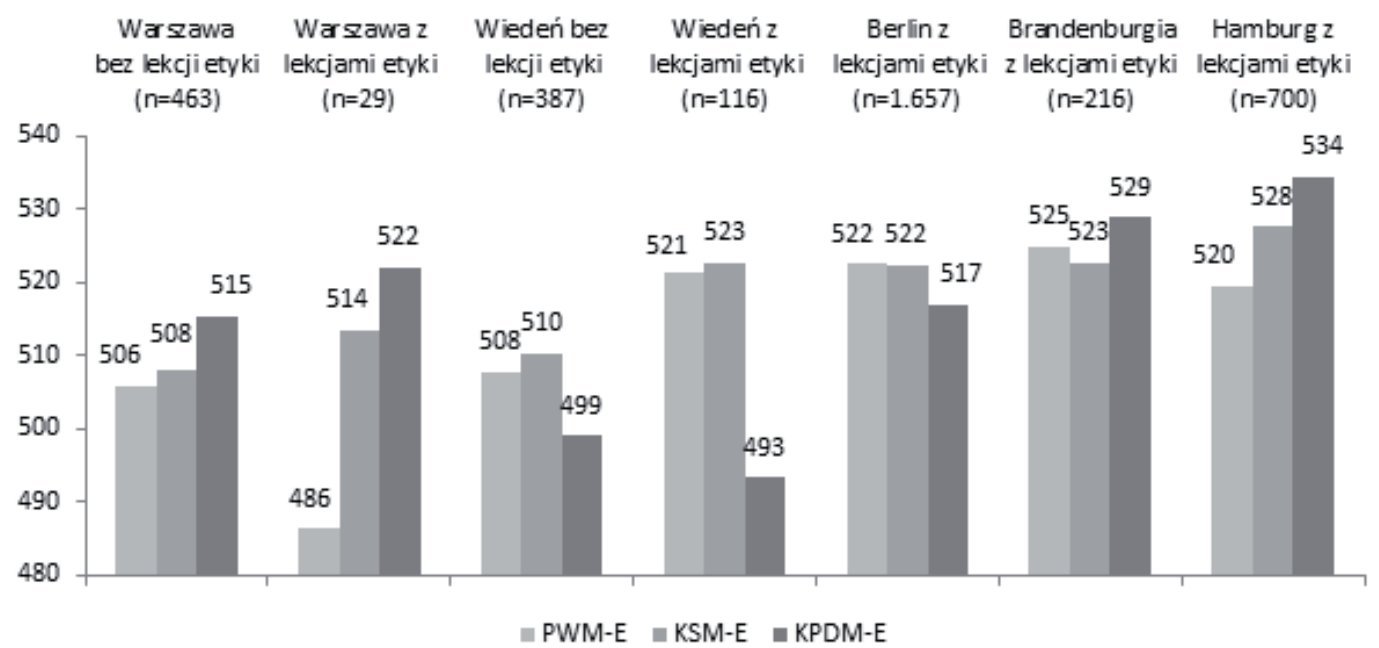

Źródło: opracowanie własne.

\section{Zakończenie}

Jak wskazano na początku, w tym referacie, oprócz zasadniczego problemu walidacji instrumentu badawczego, jakim jest TKM-EP, zamierzano sprawdzić jego przydatność do określenia w szkołach efektywności wykorzystania czasu pracy podczas jednostki lekcyjnej. W obu badaniach - warszawskim i wiedeńskim potwierdziło się, że uczniowie uczestniczący w organizowanych instytucjonalnie zajęciach z etyki osiągnęli w badaniu za pomocą TKM-EP znacząco wyższe wyniki niż ich koledzy niebiorący udziału w zajęciach z tego przedmiotu lub podobnego co do treści. Ponieważ wynik ten osiągnięto nie tylko w obszarze języka niemieckiego, można przyjąć, że opracowane przez zespół ETiK narzędzie w postaci TKM-EP jest trafnym i rzetelnym instrumentem do badania kompetencji moralno-etycznej piętnastolatków.

Planowane są dalsze badania walidacyjne, które obejmują nie tylko kraje europejskie, lecz również Chiny i Japonię. Trwają już przygotowania do adaptacji TKM-EP do tego jakże odmiennego od europejskiego kręgu kulturowego. Z pewnością badania w wymienionych krajach przyczynią się nie tylko do dalszego rozwoju zaprezentowanego instrumentu, lecz również umożliwią międzykulturowe 
analizy porównawcze w zakresie edukacji moralnej i jej ewaluacji empirycznej, a w szczególności badania szkolnych osiągnięć edukacyjnych.

Przetłumaczył z języka niemieckiego Dariusz Stępkowski

\title{
Bibliografia
}

Benner D., Nikolova R. (red.) (2016). Ethisch-moralische Kompetenz als Teil öffentlicher Bildung. Paderborn-München-Wien-Zürich: Schöningh.

Walberg H.J. (1988), Synthesis of Research on Time and Learning. „Educational Leadership", nr 45, s. 76-86.

Heller K.A., Perleth C. (2000). Kognitiver Fähigkeitstest für 4. bis 12. Klassen, Revision. KFT 4-12+. Göttingen: Beltz-Test.

\section{PRELIMINARY INTERNATIONAL VALIDATION OF THE MORAL AND ETHICAL SKILLS TEST FOR 15-YEARS-OLD STUDENTS}

\begin{abstract}
The main tool used in the international ETiK study is the Moral and Ethical Skills Test for 15-years-old students, mapped out during the realization of ETiK project in Berlin. This paper attempts to compare the data obtained through ETiK project and in the ETiK-International study conducted in Warsaw and Vienna. The validation process proved that this tool may be effectively used not only to determine students' moral and ethical skills, but also to assess the efficacy of school teaching.
\end{abstract}

Keywords: ETiK, moral and ethical skills, empirical studies in pedagogy

Stanislav Ivanov - magister psychologii, zatrudniony w Institut für Bildungsmonitoring und Qualitätsentwicklung w Hamburgu (Niemcy), członek berlińskiego zespołu ETiK. Adres mejlowy: ivanstanislav@googlemail.com. 